\title{
Eksplorasi Aspek - aspek Penghambat Penerimaan User Telemedicine pada Daerah Tertinggal di Indonesia
}

\section{Exploration of Barriers to User Telemedicine Acceptance in Disadvantaged Areas in Indonesia}

\author{
Ari Ardiansyah ${ }^{1}{ }^{*}$ \& Effy Zalfiana Rusfian2) \\ 1) Pascasarjana, Manajemen Komunikasi, Universitas Indoensia,Indonesia \\ 2) Fakultas Ilmu Sosial dan Ilmu Politik, Universitas Indonesia,Indonesia
}

Diterima: 07 Oktober 2020; Direview: 07 Oktober 2020; Disetujui: 17 Oktober 2020

*Coresponding Email: ariardiansyah4121@gmail.com

\begin{abstract}
Abstrak
Pemanfaatan Teknologi Informasi dan Komunikasi (TIK) telah menyentuh berbagai bidang kehidupan termasuk bidang kesehatan.Telemedicinesebagai hasil kemajuan TIK sangat banyak dipergunakan oleh para Bidan (user) sebagai ujung tombak pelayanan Kesehatan terutama untuk daerah tertinggal/terpencil. Dengan keragamanlatar belakang user yang ada, khususnya Bidan didaerah terpencil sebagai penerima manfaat dan penggunan TIK tersebut. Maka tujuan penelitian ini adalah mengidentifikasi faktor perilaku penggunaTelemedicine. Strategi penelitian yang dipergunakan adalah studi kasus di daerah tertinggal di Kabupaten Kupang, Nusa Tenggara Timur dimana tingkat kematian ibu hamil lahir tinggi dibandingkan dengan tingkat kematian ibu hamil di daerah lain di Indonesia. Penelitian kualitatif ini menggunakan metode wawancara secara mendalam. Hasil penelitian menunjukkan bahwa factor performance expectancy, effort expectancy, social influence, dan facilitating conditionssangat bervariasi. Selain faktor-faktor tersebut ditemukan juga pada peneltian ini bahwa keberagaman tingkat pemahaman bidan pada telemedicine sangat tergantung pada proses sosialisasi yang dilakukan oleh pemerintah daerah.
\end{abstract}

Kata Kunci: Telemedicine, Bidan, Daerah Tertinggal.

\begin{abstract}
Utilization of Information and Communication Technology (ICT) has touched various areas of life including the health sector. Telemedicine as a result of the progress of ICT is very much used by midwives (users) as the spearhead of health services, especially for disadvantaged / remote areas. Midwives in remote areas as beneficiaries and use of ICT. So the aim of this study was to identify behavioral factors of Telemedicine users. The research strategy used was a case study in an underdeveloped area of Kupang Regency, East Nusa Tenggara where the mortality rate for pregnant women born was high compared to the mortality rate for pregnant women in other regions in Indonesia. This qualitative research uses in-depth interviews. The results showed that the factors of performance expectancy, effort expectancy, social influence, and facilitating conditions varied greatly. Apart from these factors, it was also found in this study that the diversity of the midwives' level of understanding on telemedicine was highly dependent on the socialization process carried out by the local government.
\end{abstract}

Keywords: Telemedicine, Midwife, Disadvantaged Areas.

How to Cite: Ardiansyah, A., \& Rusfian, E.Z. (2020). Eksplorasi Aspek - aspek Penghambat Penerimaan UserTelemedicine pada Daerah Tertinggal di Indonesia. Journal of Education, Humaniora and Social Sciences (JEHSS).3(2):671-681. 


\section{PENDAHULUAN}

Penggunaan Teknologi Informasi dan Komunikasi (TIK) menjadi salah satu solusi untuk menyelesaikan masalah diberbagai bidang kehidupan, salah satunya adalah pada bidang Kesehatan.TIK sangat membantu dan mempermudah komunikasi dengan orang lain tanpa terbatasi oleh ruang dan waktu. Pelayanan Kesehatan juga sangat dipengaruhi oleh kemajuan teknologi informasi terutama pada peningktan kualitas pelayanan terutama pada kemerataan akses dan informasi pada kesehatan. Data di Mongolia menunjukkan bahwa dengan mempergunakan TIK yang efektif maka akan terjadi peningkatan Kesehatan Masyarakat dari tahun ketahun dengan melakukan deteksi dini terhadap potensi komplikasi (BAATAR et al., 2012). Menurut Manganello, Jennifer, et al. (2017) dalam artikelnya yang berjudul "The relationship of health literacy with use of digital technology for health information: implications for public health practice."menyebutkan pelayanan kesehatan masyarakat sangat dipengaruhi penggunaan teknologi digital, penerapan intervensi kesehatan dalam pengembangan teknlogi digital sangat efektif dalam melayani masyarakat(Manganello et al., 2015).

Menurut Wang (2013) TIK merujuk pada aspek untuk penggabungan proses informasi, komputasi, serta teknologi komunikasi (Kebbede, 2018). Hal senada diungkapkan bahwa TIK di bidang kesehatan memberikan dampak terhadap peningkatan aspek tindakan klinis, pengembangan pemberian pelayanan kesehatan dan komunikasi antar tenaga kesehatan sehingga mampu memberikan proses pengambilan keputusan melalui pertukaran informasi secara lebih efisien dengan TIK untuk menembus waktu dan ruang (Rowe, 2014). Penerapan TIK secara khusus dapat mengatasi kendala geografis bagi petugas kesehatan dalam pelaksanaan pelayanan kesehatan (Yagos et al., 2017).

Namun penerapan TIK bagi Kesehatan tidak berlaku sama dampaknya. Dampak penerapan TIK sangat tergantung dari user-nya, siapa yang akan menggunakan TIK-nya. Bagaimana persepsi user pada kegunaan dan manfaat dari TIK tersebut untuk membantu pelayanan kesehatan yang harus dia lakukan untuk masyarakat. Penerapan TIK dapat dilakukan dengan berbagai media yang tersedia dari media mainstream dan konvensional sampai dengan penerapan TIK yang sangat Advanced. Hasil penelitian Herlina, Sanjaya, \& Emilia, (2013) menunjukkan bahwa penerapan model SMS reminder sebagai media promosi kesehatan di Kecamatan Astambul Kabupaten Banjar terbukti efektif untuk menyampaikan informasi kesehatan dalam meningkatkan pengetahuan ibu hamil tentang komplikasi dan asupan gizi selama kehamilan(Herlina et al., 2013).

Penerapan TIK pada bidang Kesehatan tidah terbatas pemanfaatan pada ragam media yang digunakan namun juga muncul aplikasi TIK dalam bidang Kesehatan seperti aplikasi E- Health yang sudah merupakan isu global, yaitu aplikasi $e$-health yang bertujuan untuk meningkatkan akses, efisiensi, efektivitas, serta kualitas proses medis yang melibatkan stakeholder. Kesehatan antara lain organisasi pelayanan medis di rumah sakit, klinik, puskesmas, praktisi medis baik dokter maupun terapis, laboratorium, apotek, asuransi juga melibatkan pasien sebagai konsumen.

Lebih lanjut, kemajuan dalam TIK mampu dapat mendorong keragaman solusi kesehatan yang efektif dan efisien dalam semua aspek perawatan klinis, meningkatkan kualitas, kesetaraan, dan aksesibilitas perawatan (FENG et al., 2015). Telehealth atau istilah lainnya telemedicine merupakan layanan kesehatan jarak jauh melalui pemanfaatan teknologi komunikasi dan informasi dapat memberikan solusi pelayanan kesehatan untuk daerah terpencil dimana fasilitas kesehatan belum memadai.

Di India, telemedicine dimanfaatkan untuk menghubungkan seluruh rumah sakit termasuk rumah sakit kecil yang berada di desa(Majumdar, 2007).Sementara di Indonesia, melalui Kementeriaan Kesehatan Republik Indonesia membangun Telemedicine sejak tahun 2015 melalui pengintegrasian rumah sakit di 12 provinsi dengan melakukan tahap uji coba diagnostik. Pada sisi lain, Kementerian Desa, Pembangunan Daerah Teringgal, dan Transmigrasi (PDTT) Republik Indonesia pada 2018 menggunakan telemedicine sebagai upaya peningkatan kesehatan dalam percepatan pengentasan daerah tertinggal. 
Sistem telemedicine pada daerah tertinggal merupakan inovasi guna membantu mendeteksi faktor risiko ibu hamil dan janin serta kesejahteraan janin yang semua terkoneksi dalam satu platform databaseuntuk penelusuran dan pengawasan perawatan kehamilan dan proses pengelolaan persalinan yang lebih baik. Sistem ini diharapkan mampu memperluas upaya promotif dan preventif melalui telemedicine dan pemberdayaan sumber daya manusia menggunakan teknologi. Hal ini juga diharapkan dapat memudahkan proses pembelajaran dan meningkatkan akses dalam upaya pemerataan pelayanan kesehatandan penyelesaian terhadap masalah kurangnya distribusi tenaga kesehatan ahli di daerah.

Penelitian di Guatemala menemukan bahwa penggunaan TIK di bidang kesehatan dapat secara signifikan menurunkan tren kematian ibu dan bayi. Peneltian tersebut menunjukan penurunan jumlah kematiandari tahun 2008 sebanyak309 kematian menjadi 254 kematian dari 100.000 kelahiran pada 2012(Prieto-egido, 2015). Dibeberapa daerah, khususnya daerah terpencil, belum berhasil menurunkan angka kematian ibu dan bayi. Pemanfaatan telemedicine dapat berjalan secara maksimal dengan adanya dukungan dari faktor penerimaan dan penggunaan TIK oleh petugas kesehatan sebagai penyedia layanan(Odiwuor, Cholo Wilberforce, Jackson HO Onyuka, Fransisca Muhoho, Joseph Muchiri Chepkutto, Yegon Muthoki Lynnete, Jackline Nyaberi, Beatrice Kina, 2015). Peran penting petugas kesehatan pada pelayanan maternal adalah bidan.Menurut Myles (1975) Bidan merupakan petugas kesehatan yang memiliki fungsi penting dalam pemberian pelayanan kesehatan ibu dan bayi(Sanders et al., 2016).Berdasarkan penelitian sebelumnya, telemedicine terbukti mampu meningkatkan akses perawatan di area terpencil di Amerika.Telemedicinemembuat pasien memperoleh manfaat secara finansial dan penerapan telemedicine secara tepat mampu menghilangkan hambatan terhadap akses kesehatan dan dapat memberikan perawatan berkualitas (Ferrer-roca, 2014). Selain itu, telemedicine mampu membantu meningkatkan pelayanan kesehatan ibu di negara berkembang.Dengan menunjukan keberhasilan peningkatan kompetensi bidan dalam mengidentifikasi ibu hamil dengan risiko tinggi (Solano et al., 2015). Proses implementasi TIK pada bidan, ditemukan sejumlah hambatan. Hambatan tersebut berupa faktor internal bidan seperti akses pembelajaran bidan, akses keterampilan, akses penggunaan, dan akses motivasi (Dalton et al., 2014).

Indonesia merupakan negara kepulauan sehinggamenyebabkan terjadinya kesenjangan pelayanan kesehatan antara perkotaan dan pedesaan (Laksono \& Wulandari, 2019).Salah satu masalah yang timbul dari kesenjangan tersebut adalah tingginya Angka Kematian Ibu (AKI). AKI pada tahun 2015 adalah 305 per 100.000 kelahiran(Kementerian Kesehatan Republik Indonesia, 2017).Jika dilihat menurut pulau, pada tahun 2015 wilayah Nusa Tenggara, Maluku dan Papua memiliki AKI sebesar 489 per 100.000 kelahiran. Angka tersebut lebih tinggi dibandingkan angka nasional dan merupakan angka yang paling tinggi diantara wilayah lainseperti Sumatera, JawaBali, Kalimantan, dan Sulawesi pada tahun yang sama(Badan Pusat Statistik Indonesia).

Berdasarkan studi pendahuluan, terdapat telemedicine yang digunakan oleh bidan di Kabupaten Kupang berupa sistem yang menghubungkan mobile app yang digunakan oleh bidan dengan dokter spesialis kehamilan dan kandungan (obgyn) yang ada di pusat konsultasi untuk bertukar informasi mengenai kondisi ibu hamil.Informasi yang dikirimkan oleh bidan adalah data hasil pemeriksaan kehamilan untuk selanjutnya dapat dianalisis dan diberikan keputusan diagnosis oleh dokter obgyn.Sistem pertukaran informasi tersebut diterapkan oleh pemerintah daerah sebagai upaya peningkatan dan pemerataan pelayanan kesehatan ibu dan bayi sehingga dapat menurunkan angka kematian ibu di Kabupaten Kupang (Kemendes PDTT RI, 2018).

Kabupaten Kupang merupakan salah satu wilayah dengan kategori daerah tertinggal. Berdasarkan Peraturan Presiden Republik Indonesia, daerah tertinggal adalah daerah kabupaten yang wilayah serta masyarakatnya kurang berkembang dibandingkan dengan daerah lain dalam skala nasional (Peraturan Presiden Republik Indonesia, 2020). Daerah tertinggal memiliki karakteristik yang berbeda dengan wilayah non daerah tertinggal baik dalam aspek perekonomian, sarana dan prasarana, sumber daya manusia, kemampuan keuangan daerah, dan aksesibilitas (Peraturan Presiden Republik Indonesia, 2020).AKI Kabupaten Kupang pada tahun 2016 adalah 202 per 100.000 kelahiran (Profil Kesehatan Kabupaten Kupang 2016). Angka 
tersebut jauh di bawah angka AKI Kota Kupang sebagai ibu kota Provinsi Nusa Tenggara Timur yaitu sebesar 49 kematian per 100.000 kelahiran (Kupang, 2017).

Berbeda dengan penelitian terdahuluyang melihat hasil penerapan TIK dalam bidang kesehatan sehingga memberikan dampak terhadap kinerja bidan (Chib et al., n.d.) dan efektivitas terhadap penggunaannya(Solano et al., 2015). Penelitian ini melihat penerimaan bidan dalam penerimaan dan prilaku penggunaan terhadap teknologi informasi dan komunikasi baru di bidang kesehatan pada bidan di daerah tertinggal di Indonesia.Penerimaan dan faktor penggunaan bidan di Indonesia penerapan telemedicine di daerah tertinggal dapat dianalisa dengan menggunakan teori Unified Theory Acceptence and User of Technology (UTAUT). Faktor penerimaan dan penggunaan bidan ditentukan oleh 4 aspek yaitu, performance expectancy, effort ecpectancy, social influence, and facilitating condition (Venkatesh et al., 2012).Berdasarkan penjelasan diatas, makan penelitian ini bertujuan untuk menganalisa faktor-faktorperformance expectancy, effort ecpectancy, social influence, and facilitating condition pada prilaku bidan terhadap teknologi informasi dan komunikasi baru di bidang kesehatan pada daerah tertinggal di Indonesia.

\section{METODE PENELITIAN}

Penelitian ini menggunakan paradigma konstruktivis dengan pendekatan kualitatif. Metode penelitian ini menggunakan studi kasus. Tipe studi kasus yang digunakan adalah deskriptif. Yin (2003) mengemukakan Studi kasus deskriptif merupakan jenis studi kasus yang digunakan untuk menggambarkan intervensi atau fenomena yang terjadi di kehidupan masyarakat (Baxter \& Jack, 2010). Data primer dan data sekunder digunakan untuk mendapatkan jawaban dari tujuan penelitian. Data primer merupakan data yang didapatkan secara langsung oleh peneliti. Sedangkan data sekunder adalah data yang diperoleh dari sumber data yang sudah ada. Bidan yang bertugas di Kabupaten Kupang dijadikan sebagai data primer dengan menggunakan wawancara mendalam untuk menggali penerima telemedicine.

Metode pengambilan sampel menggunakan metode purposive sampling dengan kriteria yaitu 1) bidan desa yang bertugas di Kabupaten Kupang, dan 2) bidan desa yang pernah menggunakan telemedicine dalam praktek kebidannya.Sedangkan data sekunder akan peneliti dapatkan dari data kesehatan dan data penggunaan telemedicine oleh bidan. Teknis analisis data akan dilakukan dengan melakukan pengelompokan data sesuai kategori, pengurutan sesuai kronologi, memeriksa secara berulang dan selanjutnya melakukan pengkodean sesuai konsep UTAUT.

\section{HASIL DAN PEMBAHASAN}

\section{Performance Expectancy}

Telemedicine memberikan keuntungan kepada tenaga kesehatan terutama pada kondisi dengan sumber daya rendah (Vesel et al., 2015). Pada 2013, pengembangan dan penggunaan telemedicine mampu menjadi alat pemantauan dalam menidentifikasi ancaman pada ibu dan anak sehingga dapat dilakuakan tindakan pencegahan di Daerah Singida, Tanzania (Nyamawe, 2016). Penerapan Telemedicine di Kabupaten Kupang juga dirasakan mampu meningkatkan hasil kerja bidan.Telemedicinedapat digunanakan sebagai cara untuk memantau dan mengawasi yang lebih baik dari pada cara konvensional. Dengan bantuan telemedicineibu hamil yang memiliki resiko dapat terdeteksi lebih awal dengan data terperinci yang telah ada. Hasil tersebut sesuai dengan penyataan informan sebagai berikut:

"Ibu yang beresiko sudah ditampilkan disitu resikonya apa-apa, jadi kita bisa pantaunya lebih fokus pada ibu-ibu yang punya beresiko.Terus untuk kunjungan ulang bisa lebih terpantau seperti yang saya bilang tadi, disitukan tertera tanggal ini, nama ibu siapa-siapa yang harus kunjungan ulang begitu".

Ketersediaan fitur yang sesuai dengan kebutuhan bidan menjadi salah satu motivasi dalam penerimaan dan penggunaan telemedicine.Telemedicine yang digunakan di Kabupaten Kupang dinilai telah memiliki fitur yang lengkap.Telemedicine telah menyediakan berbagai indikatorindikator dalam pemantauan dan pengawasan terhadap ibu dan anak.Telemedicine dianggap telah mencakup semua kebutuhan bidan terkait pengawasan terhadap pasien.Sehingga dapat 674 http://mahesainstitute.web.id/ojs2/index.php/jehss mahesainstitut@gmail.com

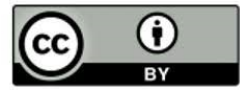


membantu bidan dalam melakukan pengawasan secara menyeluruh. Hal tersebut sesuai dengan pernyataan informan sebagai berikut,

“...KIA, nifas, bayi sudah ada. ibu nifas, ibu hamil, pas saat persalinan, jadi sudah ada semua aplikasinya yang terbaru itu..."

Menurut Key, dkk (2011) dan Aranda-Jan, dkk (2014) mengungkapkan telemedicine mampu melakukan koordinasi antara tenaga kesehatan, mengumpulkan dan menyebarluaskan data pasien, melacak tanda-tanda vital secara langsung, melakukan pengawasan dan pemantauan, dan melakukan diagnosis dari jarak jauh (Vesel et al., 2015). Penggunaan Telemedicinedi Kabupaten Kupang membantu bidan dalam penentuan keputusan diagnostik.Keputusan diagnostik merupakan hal penting karena keterbatasan kondisi geografis yang membuat kesulitan mengakses fasilitas kesehatan yang memadai di Kabupaten Kupang.Telemedicinemampu menjadi media komunikasi antara bidan dan dokter obgyn untuk membantu menentukan keputusan terkait kondisi pasien. Dalam kaitan tersebut informan mengungkapkan

“...hanya misalnya dalam kondisi gawat janin atau apa, saya rasa ini yang saya pakai dan sangat membantu. Waktu itu pernah pakai CTG (telemedicine) dan langsung dikasih saran oleh dokter ahli itu harus dirujuk karena dalam kondisi rawan janin...".

“...Itu kalau untuk kami kebidanan apalagi misalnya saya yang tugasnya di daerah terpencilkan sudah tahu nantikan kita pakai alatnya kan nanti dokternya menentukan, oh ibu pasien ini harus dirujuk, jadi kami bisa rujuk pasiennya jauh sebelum terjadi persalinan. Jadi sebelum beresiko kami sudah menganjurkan melahirkannya harus di rumah sakit begitu."

Pada performance expectancy seluruh informan sepakat bahwa kehadiran telemedicine memberikan kebermanfaatan terhadap pekerjaan mereka.Telemedicine membantu mereka dalam melakukan proses pemantauan secara lebih praktis dan terperinci terhadap ibu hamil dan bayi. Telemedicine juga membantu mereka dalam berkomunikasi dengan dokter dalam penentuan keputusan sehingga dapat melakukan tindakan pencegahan yang tepat bagi pasien yang memiliki kondisi gawat.

\section{Effort Expectancy}

Penerapan Telemedicine memiliki keunggulan fleksibilitas karena mudah digunakan dimanapun dan kapanpun.informan setuju bahwa telemedicine memiliki kemudahan pada lokasi dan waktu penggunaan. Pernyataan tersebut didukung oleh penelitian sebelumnya di Iran yang menyatakan bahwa penggunaan telemedicine pada bidan memiliki kemudahan penggunaan karena dapat digunakan dimana dan kapan saja saat dibutuhkan (Ayatollahi et al., 2019).

Penerapan telemedicine di Kabupaten Kupang juga memiliki hambatan.Hambatan dalam penggunaan telemedicine umumnya banyak terjadi pada negara berkembang seperti Indonesia.Hambatan tersebut disebabkan karena ketersediaan teknologi informasi dan komunikasi yang tidak memadai. ketersediaan akses internet yang tidak lengkap dan tidak cukup baik sehingga menjadi masalah yang terkait dengan kegagalan pada pemanfaataan telemedicine di daerah terpencil (Bali, 2018). Penerapan telemedicinedi Kabupaten Kupang telah diprediksi tidak akan berjalan lancar. Hal ini diakibatkan karena terbatasnya ketersediaan sinyal di Kabupaten Kupang dengan letak geografis terpencil.Berdasarkan pernyataan informan sebagai berikut,

“... saya sudah jelaskan sama ibu Erna (pihak 3) dengan teman-teman dari alatnya itu saya bilang, saya di sana itu daerah terpencil saya juga senang mendapatkan alat ini tetapi saya pasti akan tidak menggunakan alatnya karena sinyalnya itu di sana agak susah... ".Sehingga "...pada saat pemasangan TeleCTG (telemedicine), sementara di connect dia sinyalnya hilang, mangkanya tidak bisa terbaca...".

Pemakaian telemedicinedi Kabupaten Kupang tidak dalam kondisi ideal bagi bidan.Bidan mengalami kesulitan dalam mengoperasikan telemedicine yang diakibatkan oleh keterbatasan infrastruktur.Dalam pengoperasian telemedicine bidan harus melakukan usaha keras agar penggunaannya dapat terus dilakukan.Kesulitan bagi bidan dalam penggunaan telemedicinekarena harus berjalan sejauh 12 kilometer dari lokasi Puskesmas tempat bekerja 
untuk mendapatkan sinyal.Informan mengungkapkan kesulitan yang dialami dalam penggunaan telemedicine sebagai berikut:

"Merepotkan. Yang awal-awal itu kadang saya bilang, aduh ini bagaimana saya harus jalan ke sini ke sana gitu. Agak sedikit juga (letih), karena harus bolak balik, capenya itu ... inputnya dipertengahan sawah-sawah, di tempat itu ada pohon yang enak tempatnya untuk saya cari sinyal bagus itu ya saya parkir di situ dan saya di atas motor dan saya entri".

Besarnya usaha yang dilakukan dalam penggunaan telemedicine berdampak pada optimalisasi penggunaan alat tersebut.Sehingga mengakibatkan kendala pada pemberian data yang tidak dapat dilakukan secara cepat.Keterbatasan tersebut mengakibatkan hasil yang diharapkan dalam penerapan telemedicine tidak dapat dijalankan secara maksimal.Diakui sulit untuk melakukan pelaporan data pasien setiap hari seperti yang diutarakan yaitu:

"saya tidak bisa entrinya setiap hari karena saya ini jauh dari tempat sinyal jadi saya harus satu minggu sekali"

Penggunaan telemedicine yang belum optimal juga mempengaruhi pelayanan kesehatan yang diberikan kepada masyarakat.Kesulitan sinyal membuat pasien tidak nyaman karena membutuhkan waktu penggunaan yang lama.Sementara itu, bidan harus mengerahkan tenaga ekstra dengan terus melakukan percobaan penggunaan karena pengoperasian yang tidak berjalan lancar. Hasil tersebut merupakan analisis dari pernyataan informan yaitu:

“...memang kadang sinyalnya yang membuat kita harus uang-ulang lagi kalo belum berhasil. Jadi kadang ada dari ibu hamil yang merasa hehe terlalu lama jadi, tidak sabar ibu-ibu hamilnya. Ada yang tidak sabar...".

Pada Effort Expectancy terlihat bagaimana bidan menghadapi kendala dalam usaha penggunaan telemedicine.Dalam penggunaan telemedicine bidan tidak harus mengerahkan usaha dan tenaga tambahan.Kendala tersebut utamanya karena ketersediaan jaringan internet yang belum optimal pada daerah tersebut.Kabupaten Kupang yang memiliki lokasi terpencil tidak memiliki infrastruktur internet yang memadai.Sehingga hal tersebut membuat kinerja telemedicine tidak dapat dimanfaatkan secara optimal.

\section{Social Influence}

Pengaruh pihak lain memberikan dampak terhadap usaha penerimaan dan penggunaantelemedicine pada bidan di Kabupaten Kupang. Berdasarkan penelitian sebelumnya faktor keterlibatan kepemimpinan seperti pemerintah di dalam proses pengembangan dan implementasi telemedicine dapat membantu meningkatkan penerapan yang efektif dan kurangnya keterlibatan pemerintah dapat menjadi penghalang untuk proses penerapannya (Ross et al., 2016). Keterlibatan pemerintah dapat meningkatkan kemajuan dalam implementasi telemedicine dan membantu meghadapi hambatan yang akan terjadi (Tchao et al., 2019). Hal tersebut sejalan dengan peran otoritas kesehatan dan pemerintah di Kabupaten Kupang yang memiliki peran besar terhadap usaha penerimaantelemedicinepada bidan.Meskipun ada yang berpendapat penggunaan telemedicine sebagai wujud profesionalitas dan atas kemauan sediri.Tetapi ditemukan bahwa tanggung jawab yang diberikan oleh otoritas dan pemerintah mempengaruhi bidan untuk tetap menggunakan telemedicine. Analisis dilakukan terhadap pernyataan informan sebagai berikut:

"Saya jugakan terbeban karena pelatihannya saya yang ikut. Kalau saya tidak tetap menjalankan itu pasti ditanyakan terus, dari kabupaten juga selalu tanya, dari sehati juga selalu ditanya, jadi saya rasanya oh ini tanggung jawab saya belum terselesaikan begitu."

Dari pernyataan tersebut dapat dianalisa, adanya kesadaran dari bidan untuk menggunakan telemedicine sebagai sebuah tanggung jawab atas tuntutan yang dibebankan oleh pihak lain, dalam hal ini yaitu Kabupaten Kupang sebagai otoritas pemerintahan dan Sehati sebagai pelaksana kegiatan.

Faktor ekternal perlu diperkuat pada impelementasi telemedicine untuk mendorong penerimaan pada bidan. Penelitian sebelumnya menyebutkan bahwa dengan adanya kemitraan yang terbentuk antara pemerintah dan organisasi lain non-pemerintah menjadi potensi besar untuk pemberian pelayanan kesehatan berbasis telemedicine(Karin et al., 2013).Penggunaan 6.6. http://mahesainstitute.web.id/ojs2/index.php/jehss

(v) mahesainstitut@gmail.com

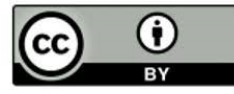


telemedicine pada prosesnya sering mengalami kendala yang dialami oleh bidan. Kehadiran pihak lain dalam menyelesaikan kendala meningkatkan motivasi penerimaan dan penggunaantelemedicine. Akses terhadap pengetahuan dan informasi penting bagi bidan untuk menggunakan telemedicine.Keterbatasan pengetahuan dan pemahaman terhadap telemedicine dapat menghambat penerimaan dan penggunaan alat tersebut. Maka dari itu diperlukan kehadiran pihak eksternal seperti fasilitator untuk memberikan informasi dan pelatihan yang memadai dalam menyelesaikan hambatan dalam implementasi (Ross et al., 2016). Informan sepakat mengungkapkan pernyataan bahwa kehadiran pihak ketiga yang membantu mereka dalam menyelesaikan permasalahan pemakaian yang terjadi.

"kalo penggunaannya kita biasa langsung sama mbak erna atau mbak riana, itu timnya mbak erna. Saat ada kendala kita langsung wa (whatsapp). Itu langsung di kasih tahu."

Telemdicineterbukti mampu meningkatkan kepercayaan diri penggunaannya(Henderson et al., 2014). Penggunaan telemedicine pada kebidanan mampu menambah keterampilan dalam penggunaan teknologi.Di Kabupaten Kupang ditemukan bahwa penerapan telemedicine mampu meningkatkan kepercayaan diri pada bidan. Penggunaan telemedicine mempengaruhi bagaimana persepsi orang lain terutama pasien kepada sosok bidan. Telemedicinedilihat sebagai suatu hal yang keren karena menggunakan peralatan yang modern.Hal tersebut diungkapkan oleh informan karena ada pandangan yang menilai diri mereka lebih baik.Informan mengungkapkan "ada yang menganggap ibu dokter".Selain itu telemedicine mampu membuat bidan merasa percaya diri terhadap otoritas dan tenaga medis lainnya dengan menggunakan teknologi sehingga menjadi lebih praktis.Rasa percaya diri tersebut menjadi salah satu faktor yang memperngaruhi motivasi penggunaan telemedicine di Kabupaten Kupang semakin tinggi. Hal tersebut diungkap informan sebagai berikut:

"ke dinas sering ditanya, ibu hamilnya berapa, ibu yang beresiko berapa, jadi saya tidak harus buka register. Tunggu ya bapak saya lihat dulu. Jadi langsung angkat hp, lihat.".

Pada tahap ini terlihat social influence yang dirasakan oleh setiap bidan memiliki pengaruh yang berbeda-beda.Kewajiban terhadap penggunaan telemedicine dari otoritas menjadi salah satu dorongan selain atas kesadaran diri sendiri. Selain itu, telemedicine memberikan dampak peningkatan rasa percaya diri terhadap pihak lain.

\section{Facilitating Condition}

Studiyang telah dilakukan menunjukan bahwa program penerapan telemedicine di daerah terpencil tidak dapat dimanfaatkan secara penuh dan efektif. Faktor-faktor seperti pasokan listrik, kecepatan internet, kurangnya infrastruktur dan teknologi yang tepat dan tenaga kesehatan yang tidak terampil mempengaruhi tingkat keberhasilan penerapan telemedicine(Bhatta et al., 2019). Sejalan sedangan hal tersebut, ketersediaan peralatan dan pengetahuan penggunan merupakan kunci dalam tahap ini.Di Kabupaten Kupang ketersediaan peralatan dan infrastuktur yang mendukung penggunaannya telemedicine oleh bidan kurang dan tidak maksimal.Penyediaan peralatan telemedicine di Kabupaten Kupang dilakukan secara tidak merata.Meskipun peralatan telah disediakan oleh pemerintah dan otoritas terkait namun mjumlahnya dinilai tidak memadai sehingga implementasi yang dilakukan tidak maksimal.Hal tersebut diungkapkan oleh informan sebagai berikut:

"...Jadi pas teman-teman bidan mau pakai.Saya di situ dengan teman-teman bidan bergantian,karena alatnya satu Puskesmas satu". Dan "Aduh itu sangat membutuhkan pak. Malah kami disini ada teman-teman saya itu bertanya ibu ini dijual tidak.Saya bilang saya tidak tahu karena saya dapat ini dari Jakarta, kami tidak tahu apakah dijual atau tidak, kami tidak tahu.Malah Puskesmas-Pukesmas itu maunya ada lagi, mereka seperti iri begitu, masa Pukesmas itu dapat kita enggak dapat alatnya gitu."

Telemedicine mengubah secara signifikan dari praktek kesehatan tradisional menjadi berbasis teknologi informasi dan komunikasi.Untuk mendapatkan hasil maksimal dalam upaya meningkatkan penerimaan bidan terhadap telemedicine perlu adanya manajemen perubahan yang sistematis. Penyediaan pengetahuan, keterampilan, dan kompetensi yang sesuai menjadi hal yang 
dibutuhkan untuk membentuk bidan sebagai pengguna telemedicine saat ini (Edirippulige \& Armfield, 2016). Pengetahuan penggunaan mendorong bidan dalam penerimaan dan penggunaantelemedicineuntuk menjalankan tugasnya.Hal tersebut diutarakan informan dimana mereka sudah mendapatkan pelatihan sebelumnya sehingga mereka dapat mengoperasikan telemedicine tersebut.Ditemukan bahwa informan memiliki keraguan pada saat awal penggunaan namun dengan pengetahuan yang diberikan melalui pelatihan membuatbidan-bidan terbiasa dalam penggunaannya.Selain itu, penggunaan telemedicine ini juga dirasa sesuai dengan kebutuhan bidan di daerah Kabupaten Kupang yang memiliki kendala geografis sehingga dibutuhkan alat untuk pemantauan ibu hamil dan bayi.

Pada facilitating condition kebutuhan bidan pada alat bantu dalam menjalankan pekerjaan menjadi salah satu motivasi penggunaan telemedicine. Namun, dibutuhkan modal pengetahuan dan peralatan yang mendukung untuk bidan dalam pengoperasian telemedicine sehingga penerimaan dan penggunaannya dapat berjalan optimal.

\section{Socialization}

Sosialisasi dan pelatihan mampu menyelesaikan kendala operasional dalam penggunaan telemedicine serta mengubah pola pikir pengguna sehingga mempercepat pemahaman dan adopsi serta penetrasi teknologi (Setiawan, 2019). Berdasarkan penelitian tersebut dibuktikan bagaimana penerimaan sebuah telemedicine dipengaruhi oleh faktor sosialisasinya.Sejalan dengan itu, sosialisasi telemedicine di Kabupaten Kupang memiliki peran penting.Sosialiasi yang telah dilakukan menjadi salah satu faktor yang mempengaruhi penerimaan dan penggunaan terhadap bidan. Bidan di Kabupaten Kupang awalnya tidak memiliki infromasi dan pengetahuan yang cukup menenai telemedicine dan cara penggunaannya. Hal ini sesuai dengan penelitian sebelumnya bahwa kurangnya literasi terhadap media baru dan komputer menjadi kendala dalam penerapan telemedicine di lapangan (Kruse et al., 2018). Kurangnya literasi terhadap telemedicine sebagai media baru di bidang kesehatan di buktikan dengan pernyataan sebagai berikut: "Sebelumnya tidak pernah dengar.Pas ada yang di sosialisasikan di Kabupaten Kupang itu baru tahu."

Sosialisasi digunakan sebagai wadah penyebaran informasi telemedicine dan bagaimana cara menggunakannya sehingga bidan dapat menerima dan menggunakan alat tersebut dengan maksimal.Sosialisasi yang dilakukan harus memiliki bentuk yang tepat. Sosialisasi perlu menggunakan carayang efektif untuk memberikan pengetahuan terhadap bidan di Kabupaten Kupang. Dari data yang didapat, di analisa bahwa cara yang paling efektif untuk memberikan informasi mengeni telemedicine dan bagaimana cara penggunaannya di Kabupaten Kupang dengan menggabungkan metode penjelasan dan praktek. Kesimpulan tersebut didapatkan berdasarkan pernyataan informan yakni

"Sudah efektif, karena kita sekaligus dengan pelatihan penggunaan alat dengan praktek ke ibu hamilnya"."... prakteknya perorang jadi disaat tidak mengerti langsung di kasih tahu oh ini cara pemakaiannya seperti ini seperti itu sudah tahu karena prakteknya perorang waktu itu".

Sosalisasi ditemukan peran bahwa tahap ini memiliki peran penting dalam mendorong percepatan penerimaan dan penggunaan telemedicinepada bidan di Kabupaten Kupang.Bidan yang bertugas di daerah tertinggal dibutuhkan sosalisasi yang efektif dengan menggunakan metode penjelasan dan praktek.Sosialisasi tersebut menjadi dasar pengetahuan bagi bidan untuk menerima dan menggunakan telemedicine secara optimal.

\section{SIMPULAN}

Bidan menjadi berada pada barisan terdepan dalam pelayanan kesehatan ibu dan anak di daerah tertinggal. Penerimaan telemedicine sebagai upaya peningkatan kualitas kesehatan ibu dan anak diterima dengan baik oleh bidan di Kabupaten Kupang. Namun prilaku bidan terhadap penggunaan telemedicine sangat beragam. Berdasarkan empat faktor yang diuji pada penelitian ini yakni performance expectancy, effort expectancy, social influence, dan facilitating conditionssangat bervariasi. faktor tersebut memiliki tingkat yang berbeda-beda terhadap setiap individu bidan.

\footnotetext{
67.8त http://mahesainstitute.web.id/ojs2/index.php/jehss mahesainstitut@gmail.com

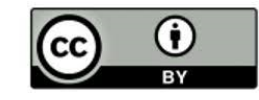


Pada faktor performance expectancy, bidan melihat penggunaan telemedicine dapat memberikan manfaat dalam peningkatan kinerja. Namun, ditemukan bahwa pada beberapa individu bidan terdapat keraguan karena infrastruktur yang tidak memadai di lokasi mereka bekerja. Faktor kedua yakni effort expectancy, terlihat adanya perbedaan usaha yang dilakukan bidan satu dengan yang lain pada daerah yang sama yaitu Kabupaten Kupang. Bidan dengan tugas di perbatasan terjauh Kabupaten Kupang harus mengeluarkan usaha lebih besar untuk menggunakan telemedicine dibanding dengan bidan yang berada di pusat pemerintahan Kabupaten Kupang. Hal ini dapat mengakibatkan penggunaan telemedicine yang tidak dapat berjalan dengan maksimal pada bidan. Pada faktor social influence, rasa tanggung jawab terhadap profesi menjadi faktor utama dalam prilaku penerimaan bidan terhadap telemedicine. Namun terungkap bahwa untuk individu bidan lain peran pemerintah dan pelaksanaa kegiatan juga menjadi pendorong penggunaan telemedicine dengan melakukan pengawasan dan pelaporan secara rutin. Akibatnya munculnya rasa kewajiban oleh bidan untuk menggunakan telemedicine tersebut. Terakhir faktor facilitating condition, menunjukan peralatan yang diberikan oleh pemerintah sebagai otoritas pelaksana program telemedicine sangat terbatas. Ditemukan bahwa penggunaan telemedicine hanya disebagian pusat kesehatan masyarakat di Kabupaten Kupang. Daerah lain yang berada di Kabupaten Kupang belum terjangkau oleh teknologi kesehatan tersebut. Keterbatasan peralatan ini membuat tenaga kesehatan yang menguasai telemedicine juga terbatas. Peralatan yang sedikit menghambat pertukaran informasi sesama bidan. Pada facilitating condition ini masalah yang menonjol dari kasus telemedicine di Kabupaten Kupang keterbatasan infrastruktur yakni sinyal yang menjadi tulang punggung implementasi telemedicine.

Selain empat faktor UTAUT tersebut, bidan di Kabupaten Kupang juga memiliki keterbatasan akses terhadap teknologi kesehatan. Oleh sebab itu, faktor sosialiasi mempengaruhi secara signifikan penerapan telemedicine. Tindakan sosialiasi yang tepat untuk penggunaan telemedicine di Kabupaten Kupang mendorong percepatan penerapan dan penggunaannya oleh bidan.Pada kasus ini, sosialisasi dengan metode penjelasan dan praktek merupakan cara yang paling efektif sehingga mempengaruhi penerimaan dan prilaku bidan terhadap telemedicine.

\section{DAFTAR PUSTAKA}

Ayatollahi, H., Abadi, M. G., \& Hemmat, M. (2019). Web and mobile-based technologies for monitoring highrisk pregnancies. 1-5. https://doi.org/10.1136/bmjhci-2019-000025

BAATAR, T., SULDSUREN, N., BAYANBILEG, S., \& SEDED, K. (2012). Telemedicine Support of Maternal and Newborn Health to Remote Provinces of. https://doi.org/10.3233/978-1-61499-152-6-27

Bali, S. (2018). We are IntechOpen, the world's leading publisher of Open Access books Built by scientists, for scientists TOP $1 \%$ Barriers to Development of Telemedicine in Developing Countries.

Baxter, P., \& Jack, S. (2010). Qualitative Case Study Methodology : Study Design and Implementation for Novice Researchers. May 2014.

Bhatta, R., Health, Y., Academy, S., \& Ellingsen, G. (2019). Opportunities and Challenges of a Rural-telemedicine Program in Nepal. June.

Carr, C., Fauveau, V., Fogstad, H., Garden, B., Johnson, P., Laski, L., Lynch, B., Mangiaterra, V., Poz, M., Rushwan, H., Campbell, E. J., Chilvers, R., Guarenti, L., Hoope-bender, P., Jolivet, R., Maliqi, B., Mcmanus, J., Minca, M., Moyo, N., ... Bucagu, M. (2011). DELIVERING SAVING.

Chib, A., Lwin, M. O., Ang, J., \& Lin, H. (n.d.). Midwives and mobiles : using ICTs to improve healthcare in Aceh Besar , Indonesia. April 2015, 37-41. https://doi.org/10.1080/01292980802344182

Dalton, J. A., Rodger, D. L., Wilmore, M., Skuse, A. J., Humphreys, S., Flabouris, M., \& Clifton, V. L. (2014). “ Who " s afraid ?": Attitudes of midwives to the use of information and communication technologies ( ICTs ) for delivery of pregnancy-related health information. Women and Birth, 27(3), 168-173. https://doi.org/10.1016/j.wombi.2014.06.010

Dinas Kesehatan Kabupaten Kupang. (2016). Profil Kesehatan Kabupaten Kupang.

Edirippulige, S., \& Armfield, N. R. (2016). Education and training to support the use of clinical telehealth : A review of the literature. $0(0), 1-10$. https://doi.org/10.1177/1357633X16632968

FENG, D., KIM, J., KHADRA, M., HUDSON, D. L., \& C. ROUX. (2015). Guest Editorial Telehealth System and Application. 19(1), 42023.

Ferrer-roca, 0. (2014). The Impact of Telemedicine on Quality. June. https://doi.org/10.1089/tmj.2009.0107 Henderson, L., Mcalpine, C., Levy, S., \& Levy, S. (2014). Growing up with confidence : using telehealth to support 
continence self-care deficits amongst young people with complex needs. 21(3).

Herlina, S., Sanjaya, G. Y., \& Emilia, O. (2013). Keefektifan SMS Reminder Sebagai Media Promosi Kesehatan Ibu Hamil di Daerah Terpencil. November, 31-38.

Javidnia, M., \& Nasiri, S. (2012). Identifying factors affecting acceptance of new technology in the industry using hybrid model of UTAUT and FUZZY DEMATEL. 2, 2383-2392. https://doi.org/10.5267/j.msl.2012.08.003

Karin, K., Tibenderana, J. K., Chb, M. B., \& Akpogheneta, O. J. (2013). Mobile Health ( mHealth) Approaches and Lessons for Increased Performance and Retention of Community Health Workers in Low-and Middle-Income Countries : A Review Corresponding Author : 15. https://doi.org/10.2196/jmir.2130

Kebbede, S. (2018). THE USE OF INFORMATION COMMIUNICATION TECHNOLOGY (ICT) IN HEALTH CARE: FINLAND VS ETHIOPIA Sirak Kebbede 2018 Laurea.

Kementerian Kesehatan Republik Indonesia. (2017). No Title.

Kruse, C. S., Karem, P., Shifflett, K., Vegi, L., Ravi, K., \& Brooks, M. (2018). Evaluating barriers to adopting telemedicine worldwide: A systematic review. 24(1), 4-12. https://doi.org/10.1177/1357633X16674087

Kupang, D. K. K. (2017). Profil ke s e hat a n. 0380.

Laksono, A. D., \& Wulandari, R. D. (2019). REGIONAL DISPARITIES OF HEALTH CENTER UTILIZATION IN RURAL ORIGINAL ARTICLE. 19(1). https://doi.org/10.37268/mjphm/vol.19/no.1/art.48

Majumdar, A. K. (2007). ADVANCES IN TELEMEDICINE AND ITS USAGE IN INDIA. 101-108. https://doi.org/10.1109/ADCOM.2007.124

Manganello, J., Gerstner, G., Pergolino, K., Graham, Y., Falisi, A., \& Strogatz, D. (2015). The Relationship of Health Literacy With Use of Digital Technology for Health Information : Implications for Public Health Practice. 12144, 1-8. https://doi.org/10.1097/PHH.0000000000000366

Nyamawe, A. S. (2016). The Role of ICT in Reducing Maternal and Neonatal Mortality Rate in Tanzania The Role of ICT in Reducing Maternal and Neonatal Mortality Rate in Tanzania. November. https://doi.org/10.5120/16658-6639

Odiwuor, Cholo Wilberforce, Jackson HO Onyuka, Fransisca Muhoho, Joseph Muchiri Chepkutto, Yegon Muthoki Lynnete, Jackline Nyaberi, Beatrice Kina, C. N. (2015). Utilization of Information Communication Technology ( ICT ) Among Health Care Utilization of Information Communication Technology ( ICT ) Among Health Care Providers in Gatundu North District of Kiambu County, Kenya. January.

Peraturan Presiden Republik Indonesia. (2020). 3. 232014 (Issue 018390).

Prieto-egido, I. (2015). TulaSalud: An m-health system for maternal and infant mortality reduction in Guatemala. July. https://doi.org/10.1177/1357633X15575830

Ross, J., Stevenson, F., Lau, R., \& Murray, E. (2016). Factors that influence the implementation of e-health : a systematic review of systematic reviews ( an update ). Implementation Science, 1-12. https://doi.org/10.1186/s13012-016-0510-7

Rowe, M. (2014). Information and communication technology in health: A review of the literature INFORMATION AND COMMUNICATION TECHNOLOGY IN HEALTH : A REVIEW OF THE LITERATURE. July.

Sanders, J., Reader, M. P. H., Hunter, B., Rcm, R. M., Warren, L., \& Midwifery, R. M. (2016). A wall of information? Exploring the public health component of maternity care in England. Midwifery, 34, 253-260. https://doi.org/10.1016/j.midw.2015.10.013

Setiawan, A. B. (2019). Telemedicine Design for Rural Areas as a Framework of e-Health Implementation. 2018 International Conference on ICT for Rural Development (IC-ICTRuDev), 75-80.

Solano, M., E, K., M, C., Scheffer, C., Easterling, T., Geerts, L., Beach, K., \& Kim, Y. (2015). Asynchronous Telemedicine with Ultrasound: Improving Maternal Health in Developing Countries. 10, 2316-2319.

Tchao, E. T., Acquah, I., Kotey, S. D., Aggor, C. S., \& Kponyo, J. J. (2019). On Telemedicine Implementations in Ghana. 10(3), 193-201.

Venkatesh, V., Morris, M. G., Davis, G. B., \& Davis, F. D. (2012). User Acceptance of Information Technology: Toward a Unified View. 27(3), 425-478.

Vesel, L., Hipgrave, D., \& Dowden, J. (2015). Application of mHealth to improve service delivery and health outcomes : Opportunities and challenges.

Widodo, T. (2018). Penerapan Model Unified Theory of Acceptance and Use of Technology ( UTAUT ) untuk Menganalisis Minat Pengguna Smartphone Di Kota Bandung PENERAPAN MODEL UNIFIED THEORY OF ACCEPTANCE AND USE OF. October.

Yagos, W. O., Olok, G. T., \& Ovuga, E. (2017). Use of information and communication technology and retention

680 http://mahesainstitute.web.id/ojs2/index.php/jehss mahesainstitut@gmail.com


of health workers in rural post-war conflict Northern Uganda : findings from a qualitative study. $B M C$ Medical Informatics and Decision Making, 1-8. https://doi.org/10.1186/s12911-016-0403-3 